Int. J. Plant Sci. 166(6):909-924. 2005.

(c) 2005 by The University of Chicago. All rights reserved.

$1058-5893 / 2005 / 16606-0003 \$ 15.00$

\title{
COMPARATIVE POLLEN DEVELOPMENT IN DIOSCOREALES
}

\author{
Peter Schols, ${ }^{1, *}$ Carol A. Furness, $†$ Vincent Merckx,* Paul Wilkin, $†$ and Erik Smets* \\ *Laboratory of Plant Systematics, Institute of Botany and Microbiology, Katholieke Universiteit Leuven, \\ Kasteelpark Arenberg 31, B-3001 Leuven, Belgium; and tRoyal Botanic Gardens, \\ Kew, Richmond, Surrey TW9 3AB, United Kingdom
}

\begin{abstract}
Pollen and orbicule ontogeny in representatives of three genera of Dioscoreales-Narthecium ossifragum Huds. (Nartheciaceae), Tacca artocarpifolia Seem. and Tacca chantrieri André (Dioscoreaceae), and Dioscorea communis (L.) Caddick \& Wilkin (Dioscoreaceae)—is described and illustrated using LM, SEM, and TEM. The main difference is in microsporogenesis, which is successive in Narthecium Huds. and simultaneous in Tacca J.R. \& G. Forst. and Dioscorea L. This is reflected in the tetrad configuration but not in the apertures: Narthecium and Tacca are monosulcate, while Dioscorea has two equatorial apertures. Other features of pollen development are similar in all three genera. Exine development starts at the proximal pole, and during the tetrad stage, the exine remains thicker at this pole. Intine development begins before mitosis. A conspicuously channeled intine forms beneath the aperture(s) in all three genera, and in Tacca it also occurs in nonapertural regions. After mitosis, the generative cell is situated at the proximal pole in all genera. Orbicules are present in Narthecium and Dioscorea but not in Tacca, although it has a secretory tapetum. In the tetrad stage, pro-orbicules appear on the tapetum in Narthecium and Dioscorea, and pro-sporopollenin is consequently deposited to form the orbicule wall.
\end{abstract}

Keywords: intine, microsporogenesis, monocotyledons, orbicules, pollen ontogeny, systematics, tapetum, tetrads.

\section{Introduction}

The current circumscription of the order Dioscoreales, comprising three families (Nartheciaceae, Burmanniaceae, and Dioscoreaceae), is relatively recent, following analysis of new morphological and molecular data (Caddick et al. 2000, 2002a). Data on microsporogenesis and pollen morphology have proved crucial to the resolution of relationships within lilioids (Rudall et al. 1997), Dioscoreales (Caddick et al. 1998), and Dioscoreaceae (Schols et al. 2001, 2003, forthcoming). These articles provided significant palynological data and indicated the need for pollen ontogenetic studies within Dioscoreales. In this order (fig. 1 ), a change from successive to simultaneous microsporogenesis occurs (Caddick et al. 1998) as well as a switch from monosulcate to the less frequent disulculate pollen type (Schols et al. 2003, forthcoming), and examination of pollen ontogeny could offer some insight into the mechanisms causing these changes. Additionally, such a study could also provide more data on the development of the distinctive intine observed by Schols et al. (2001), the tapetum type, and the development of orbicules, small sporopollenin bodies reported to be abundant within Dioscorea (Schols et al. 2001, 2003). To date, however, pollen ontogeny has not been studied in detail in Dioscoreales apart from obser-

${ }^{1}$ Author for correspondence; e-mail peter.schols@bio.kuleuven.ac.be. Manuscript received January 2005; revised manuscript received June 2005. vations of microsporogenesis (Caddick et al. 1998; Furness and Rudall 1999).

This article aims to document the pollen ontogeny of three genera of Dioscoreales using Narthecium ossifragum Huds. (Nartheciaceae), Tacca artocarpifolia Seem. and Tacca chantrieri André (Dioscoreaceae), and Dioscorea communis (L.) Caddick \& Wilkin (Dioscoreaceae) as exemplar taxa. These species were chosen because they represent different parts of the Dioscoreales phylogeny and because they encompass the range of pollen characters found in the order (fig. 1). Nartheciaceae are sister to the rest of Dioscoreales and are successive and monosulcate, the most common combination within monocots (Caddick et al. 1998, 2002a; Furness and Rudall 1999). Dioscorea L. and Tacca J.R. \& G. Forst. both have simultaneous microsporogenesis (Caddick et al. 1998). Dioscorea communis is disulculate, the most common aperture type in Dioscorea, which is a synapomorphic character (fig. 1), while Tacca is monosulcate (Schols et al., forthcoming). In this article, the development of the pollen grains, tapetum, and orbicules in the three selected genera is described and compared both between these taxa and with other monocots. Burmanniaceae, the third family in the order, is not represented here. They have successive microsporogenesis, like Nartheciaceae (Chakrapani and Raj 1971; Caddick et al. 1998). They are mycoheterotrophs, which cannot be grown outside their natural habitat among the leaf litter in moist tropical forests, making it extremely difficult to obtain material for ontogenetic observations. 


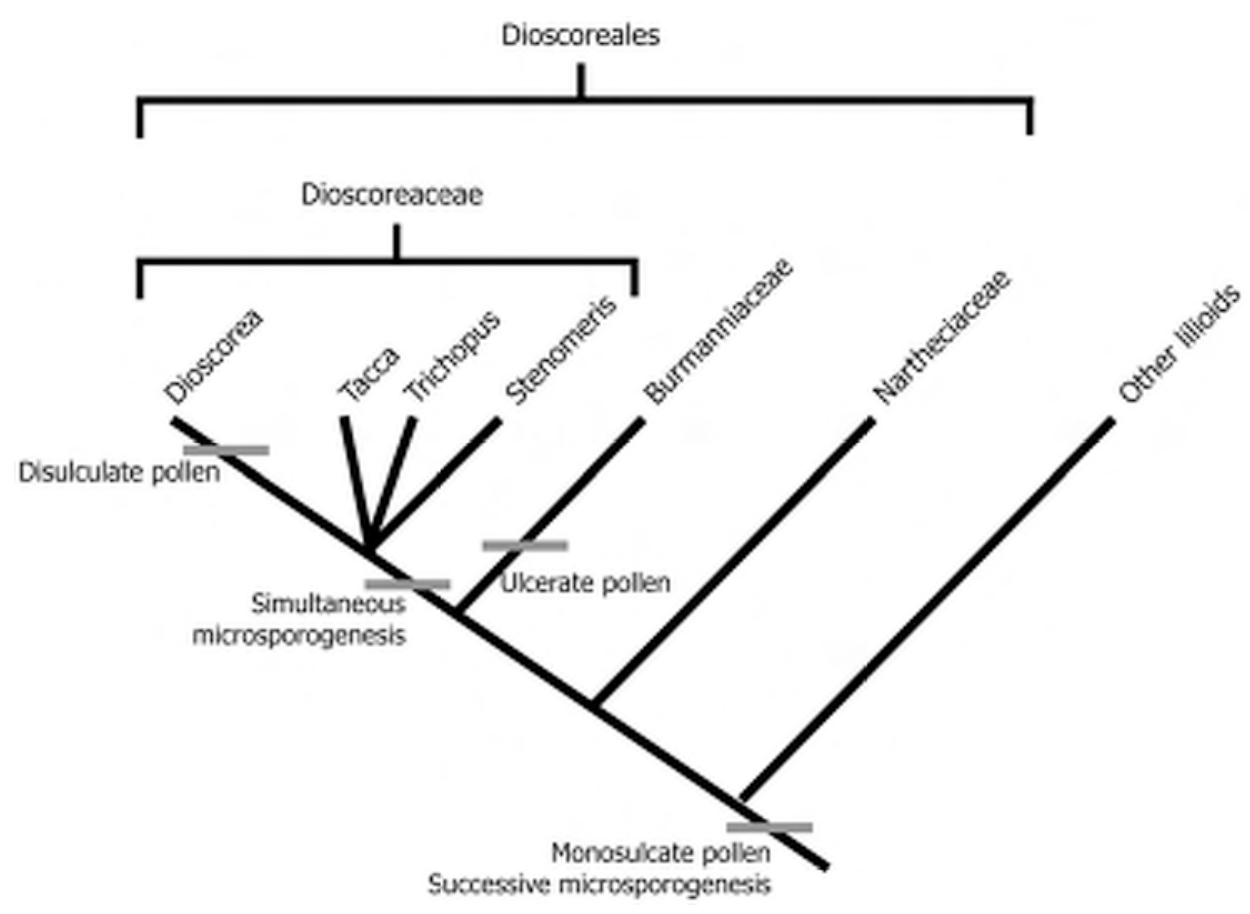

Fig. 1 Evolution of pollen characters in Dioscoreales, based on Caddick et al. (2002b). Dioscorea section Stenophora, sister to other Dioscorea species, is also monosulcate (Schols et al., forthcoming).

\section{Material and Methods}

\section{Material}

Material of Narthecium ossifragum was collected in the wild, and a voucher specimen was deposited in the herbarium of the Royal Botanic Gardens, Kew (K: Furness and Rudall 1). Material of Tacca was collected from specimens in the living collections of the Royal Botanic Gardens, Kew (Tacca artocarpifolia: HK: 1996-946; Tacca chantrieri: HK: 1986-329). For Dioscorea communis, inflorescences were obtained from a specimen grown in the botanical garden of the Institute of Botany and Microbiology, Katholieke Universiteit Leuven. Voucher specimens have been deposited in the herbarium of Leuven.

\section{Methods}

SEM. Fresh flowers were fixed in $2 \%$ glutaraldehyde in $0.05 \mathrm{M}$ sodium cacodylate buffer $(\mathrm{pH} \mathrm{7.4)}$ for $24 \mathrm{~h}$ and dehydrated through an acetone series. They were critical-point dried in a Balzers CPD 030. Following critical-point drying, anthers were removed, and pollen grains were mounted on stubs with carbon strip tape. Micrographs were taken using digital imaging on a JEOL JSM 5800 scanning electron microscope at $80 \mathrm{kV}$.

LM and TEM. Anthers of N. ossifragum, T. artocarpifolia, and T. chantrieri were placed in $2.5 \%$ glutaraldehyde in $0.1 \mathrm{M}$ cacodylate buffer ( $\mathrm{pH} 7.2$ ), deaerated under vacuum for $1 \mathrm{~h}$, and fixed for $16-20 \mathrm{~h}$ at $4{ }^{\circ} \mathrm{C}$. They were washed in cacodylate buffer, postfixed in $1 \%$ buffered osmium tetroxide for $3 \mathrm{~h}$ at room temperature, and washed again. Tissues were dehydrated through an ethanol series followed by three changes of $100 \%$ ethanol and embedded in LR White resin (London Resin, Reading, UK) in gelatin capsules. Fresh whole anthers of D. communis were fixed in $2 \%$ glutaraldehyde in $0.05 \mathrm{M}$ sodium cacodylate buffer ( $\mathrm{pH} 7.4$ ) for $24 \mathrm{~h}$ and postfixed in $2 \%$ osmium tetroxide for $1 \mathrm{~h}$. Anthers were bloc stained with uranyl acetate $(1 \%)$ for $10 \mathrm{~min}$, dehydrated through an acetone series followed by propylene oxide, and embedded in araldite. For all taxa, semithin sections were stained with thionin $(0.1 \%)$ and methylene blue $(1 \%)$ and examined using a Labophot light microscope and a Nikon AFX-II camera attachment. Ultrathin sections on copper grids were stained with uranyl acetate and lead citrate. Electron micrographs were taken using a Zeiss EM906 transmission electron microscope at $80 \mathrm{kV}$.

Measurements. Measurements were carried out on digital SEM and TEM images using Carnoy 2.1 for Mac OS X (Schols et al. 2002).

Terminology. Terminology follows the international glossary (Punt et al. 1998). Although anther and pollen development is a continuous process, we have organized the descriptions of developmental events and cytological changes in four distinct stages-microsporocytes (microspore mother cells), tetrads, free microspores, and mature pollen grainsfollowing the usual convention for pollen development (e.g., Kreunen and Osborn 1999).

\section{Results}

\section{Narthecium}

Microsporocyte stage (fig. 2A-2D). The anther wall typically consists of an epidermis; an endothecium; one, two, or 

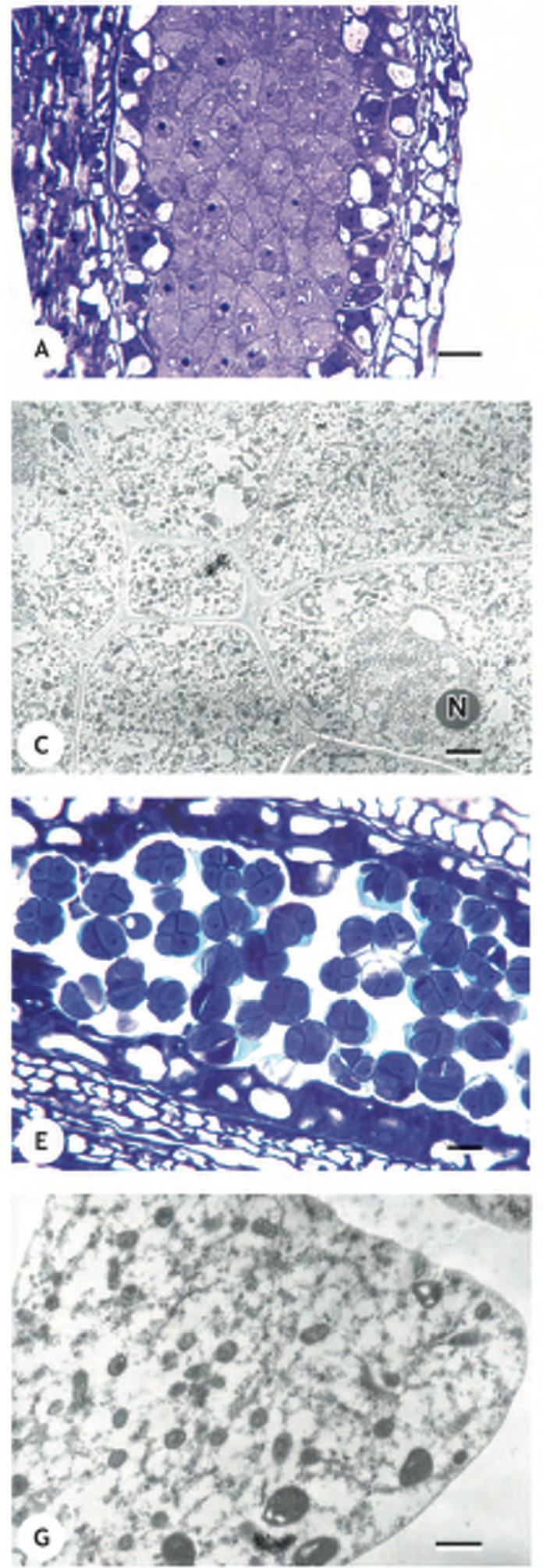
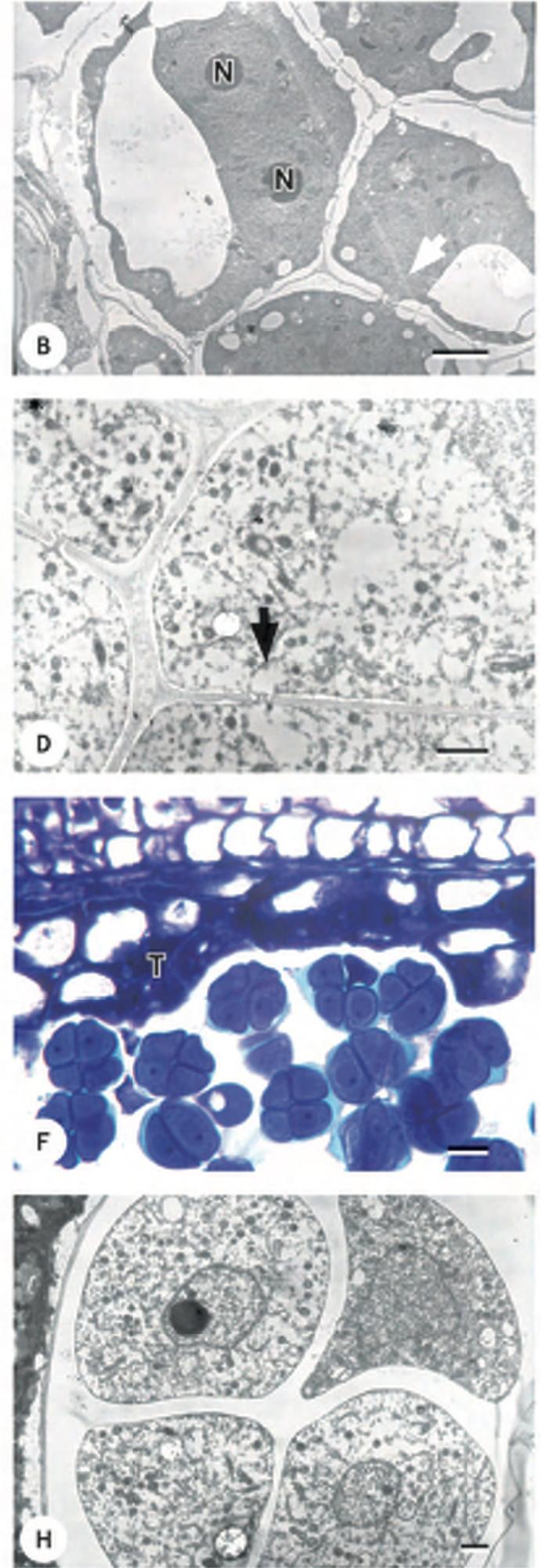

Fig. 2 Narthecium ossifragum, microsporocyte stage and tetrad stage. $A-D$, Microsporocyte stage. $A$, Section through a single locule showing early microsporocytes and densely staining tapetum (LM). B. Section through a tapetal cell with two nuclei (N) (TEM). C, Section through microsporocytes surrounded by callose (TEM). D, Detail of $C$ showing a cytomictic channel (arrow) (TEM). E-H, Tetrad stage. E, Section through a locule filled with tetragonal tetrads (LM). F, Detail of $E$. The tapetum (T) contains many vacuoles and densely staining substances (LM). $G$, Section through one microspore in a tetrad at the early tetrad stage (TEM). H, An early tetragonal tetrad, with no indication of wall formation (TEM). Bars $=10 \mu \mathrm{m}$ in $A, E ; 1 \mu \mathrm{m}$ in $B-D, G, H$. 
rarely three middle layers; and a tapetum. The tapetum is mostly uninucleate, sometimes binucleate, and one or two layered (fig. 2A, 2B). Microsporocytes are ca. $25 \mu \mathrm{m}$ long and $15 \mu \mathrm{m}$ wide, angular in shape with large nuclei (fig. 2C). They are interconnected through cytomictic channels of ca. $0.5 \mu \mathrm{m}$ diameter (fig. $2 B, 2 D$ ), which allow intercell communication.

Tetrad stage (figs. 2E-3D). Following meiosis, tetragonal tetrads of haploid microspores randomly fill the entire space of the anther locule. Each microspore in a tetrad is surrounded by a thick callose envelope (fig. $2 E-2 H$ ). A fibrillar surface coat develops between the callose and the plasmalemma of each microspore. This primexine matrix has about the same thickness over the entire surface, with no visible differentiation between the proximal pole and the distal pole, where the aperture will be formed (fig. $2 \mathrm{G}, 2 \mathrm{H}$ ). This is the most productive stage for the tapetal cells, and they stain very densely (fig. 2E, 2F; fig. 3C). Lipid droplets and proorbicules, originating by exocytosis, are visible in depressions of the tapetal plasmalemma (fig. 3D). In microspores in slightly older tetrads, T-shaped electron-dense material is radially oriented in the proximal part of the plasmalemma surface coat; these elements are the initiation of the columellae and tectum. Wall deposition seems more developed at the proximal pole: at the late tetrad stage, the exine is ca. $0.4 \mu \mathrm{m}$ thick at the proximal pole and $0.2 \mu \mathrm{m}$ at the distal pole (fig. 3A). An incomplete tectum starts to form. The aperture sites become visible for the first time: they lack columellae, and the exine elements above the aperture are very thin or even nonexistent. One elongated aperture develops at the distal pole, leading to monosulcate pollen grains (fig. $3 B$ ). We could not find any intermediate stages between early and late tetrads, indicating that the deposition of the first exine elements occurs very rapidly and the foot layer originates soon thereafter. Entire tetrads in the late tetrad stage have a diameter of ca. $17 \mu \mathrm{m}$. In this phase of anther development, the tapetal cells are still in a state of high metabolic activity, indicated by their many organelles and cytoplasmic inclusions.

Free microspore stage (figs. 3E-4B). Breakdown of the callose wall marks the transition from the tetrad stage to the free microspore stage. In the earliest free microspore stage, the anthers contain microspores still in a tetrad arrangement, with residual callose present between them (fig. 3E). By the time the callosic envelope has completely dissolved and the microspores are released from the tetrads, their exines have increased considerably in thickness to ca. $0.8 \mu \mathrm{m}$ (fig. $3 G$, $3 H)$. Microspores at this stage are characterized by the presence of one or more large vacuoles and have a diameter of ca. $20 \mu \mathrm{m}$ (fig. $3 F$ ). In the late free microspore stage, each microspore still contains many vacuoles as well as starch and lipid droplets. The intine develops underneath the aperture and protrudes together with part of the protoplasm (fig. 4A). The intine is almost exclusively present in the apertural region and contains radially oriented channels. Intine initiation precedes mitosis since the intine layer is clearly present at the late free microspore stage. Rather large orbicules of ca. $0.8 \mu \mathrm{m}$ diameter line the surface of the tapetal cells (fig. $4 B$ ) on the inner and outer tangential walls as well as on the radial surfaces. These orbicules have an electron-lucent core of
$0.2 \mu \mathrm{m}$ diameter (fig. $4 B$ ). At this stage, the tapetum starts to degenerate.

Pollen grain stage (fig. 4C-4H). In mature pollen grains, the exine is ca. $1.2 \mu \mathrm{m}$ thick. The foot layer, tectum, and columellae are now well differentiated (fig. 4C, 4D). Narthecium ossifragum has a perforate sexine. The intine develops further and also becomes visible at nonapertural sites. Two intine layers are observed. A channeled layer is very conspicuous in the apertural region and very thin in nonapertural regions (fig. $4 D, 4 E$ ). Seen in tangential section, the channels are arranged in a characteristic polygonal structure (fig. $4 F)$. The second layer is a thin endintine covering the entire pollen grain (fig. $4 D$, arrows). After mitosis, the generative cell is situated at the proximal pole at the opposite side of the aperture (fig. 4C, 4D). Starch seems to be the main cytoplasmic storage product, since the pollen contains many compound starch grains. The tapetum has almost entirely degenerated, leaving cytoplasmic remnants together with orbicules on the locule walls (fig. $4 G, 4 H$ ). The orbicules have a diameter of ca. $1.3 \mu \mathrm{m}$ and an electron lucent core of ca. $0.5 \mu \mathrm{m}$.

\section{Tасса}

Microsporocyte stage (fig. 5A, 5B). An epidermis, endothecium, one middle layer, and one layer of tapetal cells surround the microsporocytes. The tapetum is mostly uninucleate or sometimes binucleate. The microsporocytes are angular in shape (fig. 5A), and late microsporocytes are surrounded by callose walls (fig. $5 B$ ).

Tetrad stage (fig. 5C-5F). The tetrad stage in Tacca is very similar to that in Narthecium. The main difference is the presence of tetrahedral tetrads in Tacca (fig. 5C) that are correlated with simultaneous microsporogenesis. A thick callose envelope surrounds each tetrad unit (fig. 5D). The cytoplasm of the microspores contains many vacuoles and Golgi vesicles. Between the callose and the plasmalemma, a fibrillar surface coat develops (fig. 5F). As in Narthecium, T-shaped electron-dense material is radially oriented in the plasmalemma surface coat. This is the initiation of the columellae and tectum. Wall deposition is more developed at the proximal pole at this stage. As in Narthecium, the exine is ca. $0.2 \mu \mathrm{m}$ thick at the proximal pole and $0.1 \mu \mathrm{m}$ thick at the distal pole. Where the plasmalemma is pressed directly against the callose wall at the distal pole, exine is completely lacking, and this region will become the apertural site (fig. $5 E)$. Entire tetrads have a diameter of ca. $34 \mu \mathrm{m}$. This is about twice the size of tetrads in Narthecium and reflects the larger size of pollen in Tacca (ca. $50 \mu \mathrm{m}$ compared with ca. $20 \mu \mathrm{m}$ in Narthecium; Schols et al., forthcoming). In this phase of anther development, the tapetal cells are still in a state of high metabolic activity, indicated by their many organelles and cytoplasmic inclusions. Orbicules or proorbicules were not observed.

Free microspore stage. Unfortunately, observations of the free microspore stage in Tacca are not available since pollen development often aborted (cytoplasm was lacking) after the tetrad stage in the material of Tacca chantrieri examined. Observations of the pollen grain stage are based on sections through a mature anther of another Tacca species (Tacca artocarpifolia). 

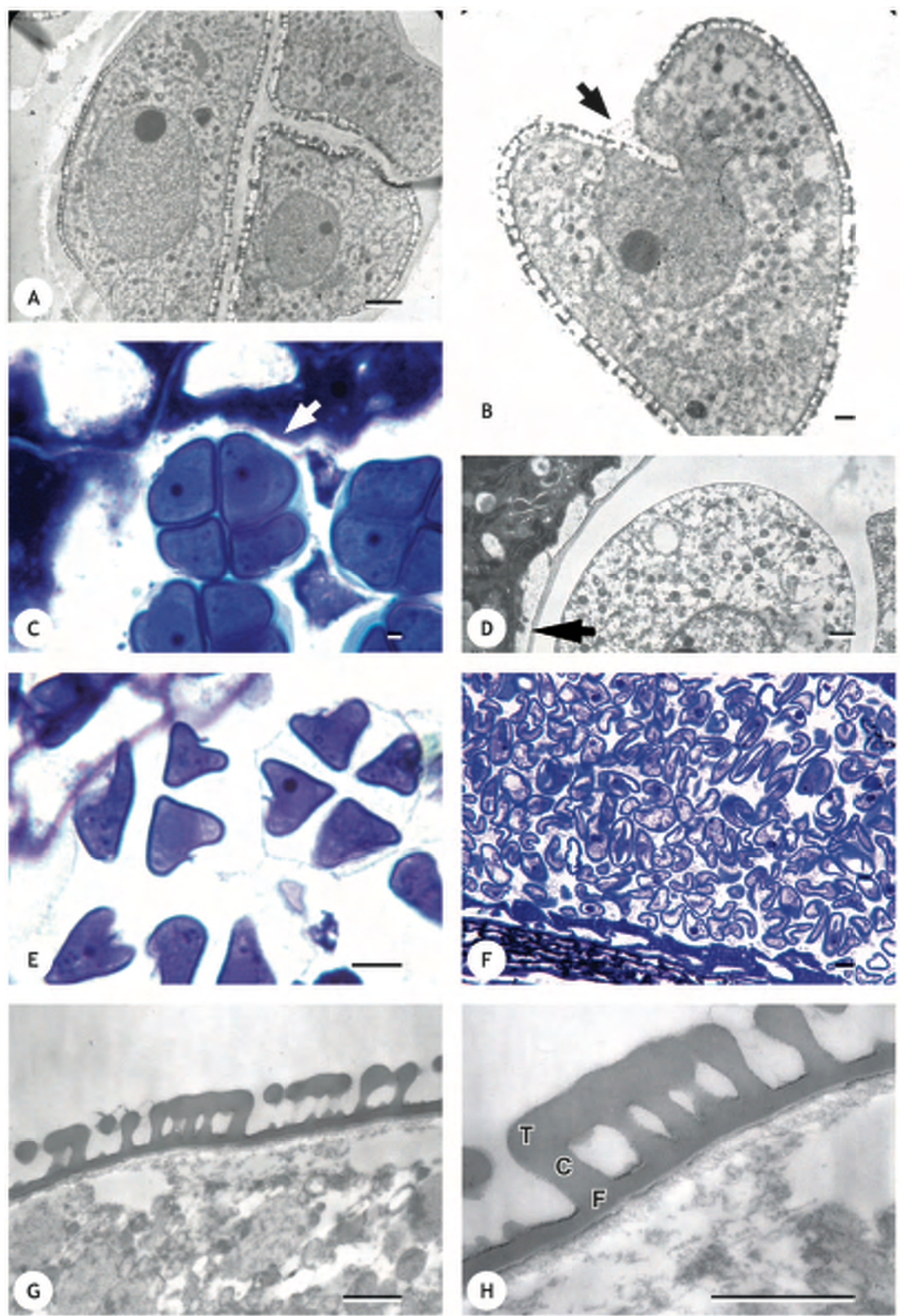

Fig. 3 Narthecium ossifragum, tetrad stage (continued) and microsporocyte stage. A, Late tetrad with T-shaped elements forming the procolumellae and the pro-tectum (TEM). B, Detail of one microspore from a tetrad with exine and aperture site (arrow) (TEM). C, Tetragonal tetrads. The single sulci are visible at the distal poles (arrow) (LM). D, Detail of the tapetum releasing pro-orbicules (arrow) in cuplike depressions of the plasma membrane (TEM). E-H, Free microspore stage. E, Early free microspores being released from the tetrads as the callose walls dissolve (LM). F, Anther locule with microspores in the vacuolate stage, with one or more large vacuoles occupying a large part of each microspore. The microspores appear wrinkled (LM). G, Developing exine during the vacuolate stage: tectum, columellae, and foot layer are already present (TEM). $H$, Detail of $G$ showing tectum $(T)$, columellae $(C)$, and foot layer $(F)($ TEM). Bars $=1 \mu \mathrm{m}$ in $A-D, G, H$; $10 \mu \mathrm{m}$ in $E, F$. 

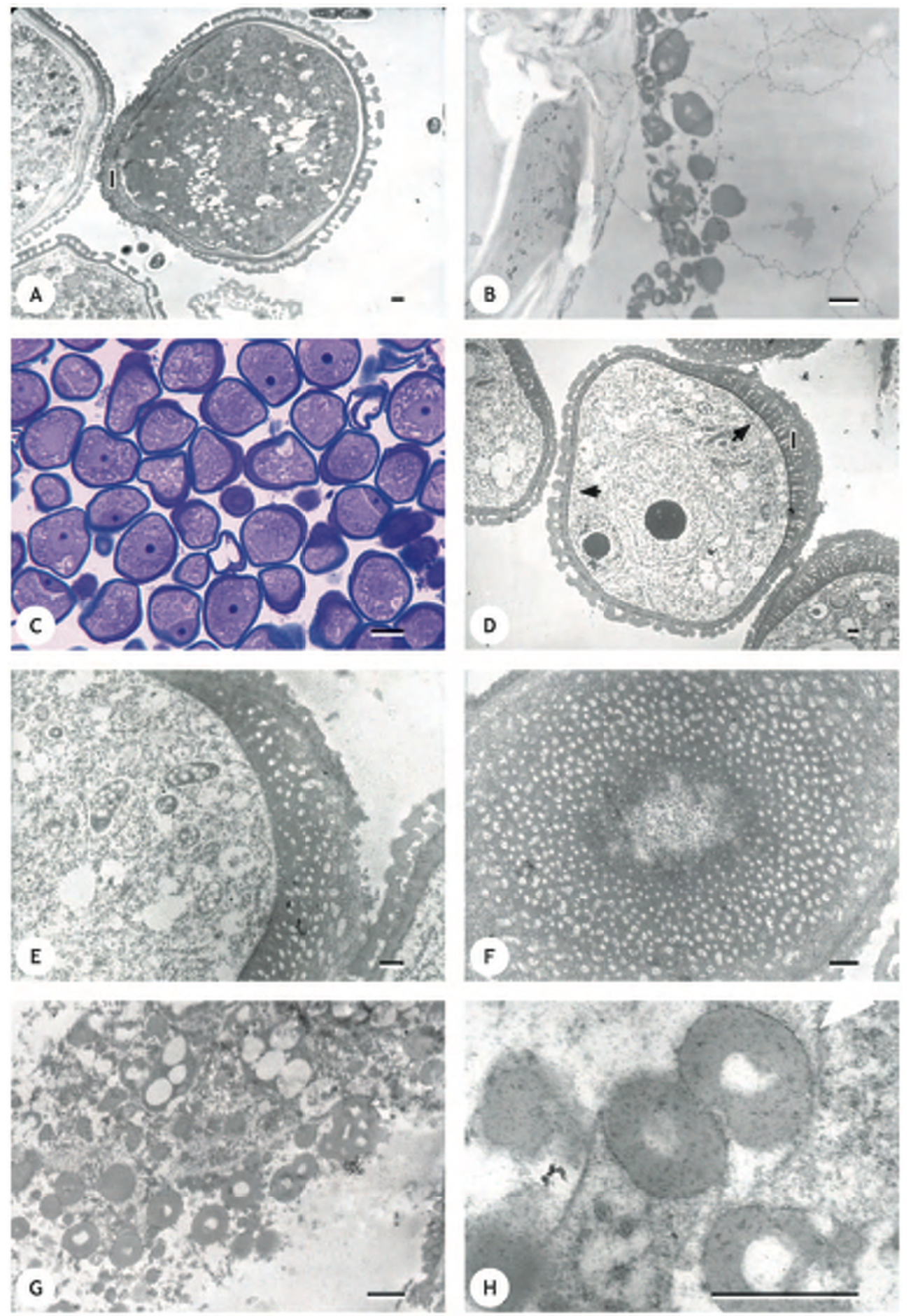

Fig. 4 Narthecium ossifragum. Free microspore stage (continued) and mature pollen grain stage. A, B, Free microspore stage. A, Late microspore with a well-developed exine. Intine $(I)$ is already present beneath the sulcus, and the cytoplasm contains many starch grains (TEM). $B$, Orbicules at the late microspore stage with electron-lucent cores and electron-dense walls. The tapetum is degenerating. $\mathrm{C}-\mathrm{H}, \mathrm{Mature}$ pollen grain stage. $C$, Pollen grains in an anther locule. Both the vegetative and generative cells are visible in some grains. The generative cell is always located at the proximal pole, opposite the aperture. The intine stains densely beneath the aperture (LM). $D$, Section through a mature pollen grain. The generative cell is located opposite the aperture as seen in A. Arrows indicate the difference in intine thickness between the apertural and nonapertural sites. The intine (I) beneath the aperture is thick and channeled (TEM). E, Transverse section through the apertural intine of a mature pollen grain (TEM). F, Tangential section through the apertural intine of a mature pollen grain. The electron-lucent channels are arranged in polygonal structures (TEM). G, Orbicules on the tapetal remnants. The electron-dense wall has thickened compared with the free microspore stage (TEM). $H$, Detail of orbicules with a darker peripheral layer on the outside (arrow) (TEM). Bars $=1 \mu \mathrm{m}$ in $A, B, D-H ; 10 \mu \mathrm{m}$ in $C$. 

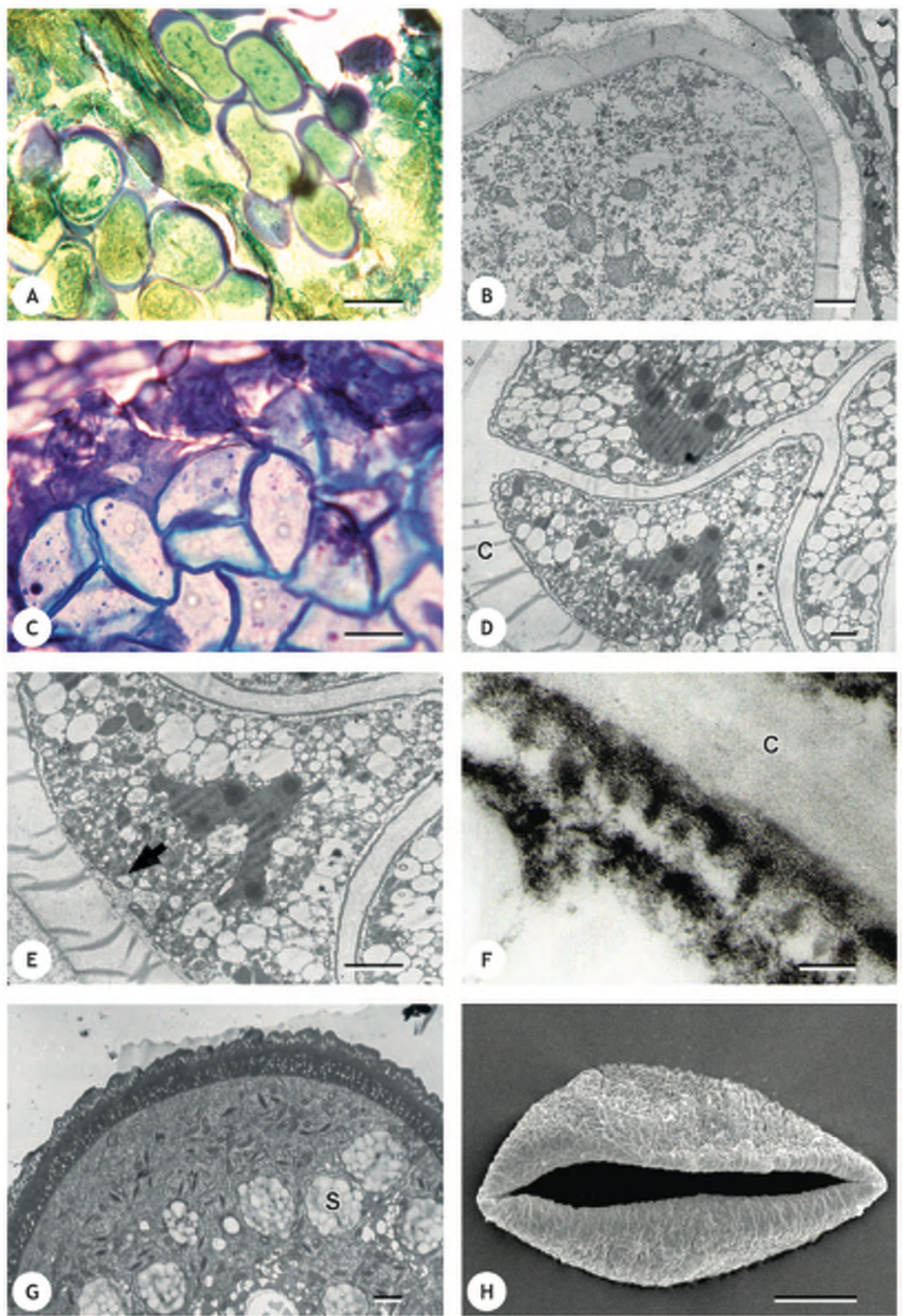

Fig. 5 Tacca chantrieri, microsporocyte stage, tetrad stage, and mature pollen grain stage. $A, B$, Microsporocyte stage. $A$, Section through an anther locule with microsporocytes surrounded by densely staining callose walls (LM). B, Detail of a microsporocyte surrounded by callose (TEM). C-F, Tetrad stage. $C$, Section through a locule filled with tetrahedral tetrads (LM). D, A tetrahedral tetrad with a highly undulating plasma membrane and thick callose wall $(C)(T E M)$. E, Detail of $D$ showing the future aperture site at the distal pole (arrow) where no exine deposition occurs (TEM). F, Exine synthesis at the proximal pole, underneath the callose (C) (TEM). $G, H$, Mature pollen grain stage. $G$, Young pollen grain containing many compound starch grains. The exine is well developed, and a thick, channeled intine is present around the entire pollen grain (TEM). $H$, Mature pollen grain with a distal sulcus (SEM). Bars $=10 \mu \mathrm{m}$ in $A, C, H ; 1 \mu \mathrm{m}$ in $B, D-G$. 
Pollen grain stage (figs. 5G-6C). After mitosis, the generative cell is situated at the proximal pole at the opposite side of the aperture (fig. 6A). In mature pollen grains, the exine is ca. $1.4 \mu \mathrm{m}$ thick with a well-differentiated foot layer, tectum and columellae. Tacca artocarpifolia has monosulcate pollen (fig. $5 \mathrm{H}$ ) and rugulate sexine ornamentation (fig. 6B). The intine develops further and also becomes visible at nonapertural sites. One channeled intine layer forms, and this is ca. $1.1 \mu \mathrm{m}$ thick in both apertural and nonapertural regions (fig. $5 G)$, although this pollen grain is not fully mature. The intine channels are arranged in a polygonal structure. Each pollen grain contains many compound starch grains, and starch seems to be the main cytoplasmic storage product, as in Narthecium. At this stage, the tapetum has almost entirely degenerated, and there are no orbicules present on the locule wall (fig. 6C).

\section{Dioscorea}

Microsporocyte stage (fig. 7A-7E). In addition to the epidermis and endothecium, one middle layer and one layer of tapetal cells surround the microsporocytes. The tapetum is mostly uninucleate or sometimes binucleate and contains many vacuoles and densely staining substances (fig. 7A, 7B). The microsporocytes are angular in shape and ca. $25 \mu \mathrm{m}$ long and $20 \mu \mathrm{m}$ wide (fig. $7 B, 7 C$ ). They are surrounded by callose and contain many vesicles (fig. $7 C-7 E$ ).

Tetrad stage (fig. $7 \mathrm{~F}-8 \mathrm{H})$. After meiosis, tetrahedral tetrads of haploid microspores fill the anther locules (fig. $7 F-$
$7 H)$. Each tetrad unit is surrounded by a callose envelope. The cytoplasm of the microspores is rich in vacuoles, ribosomes, and Golgi vesicles. Golgi vesicles are abundant near the plasmalemma in particular and are probably involved in the initiation of the primexine, which is not yet present. In slightly older tetrads, a fibrillar surface coat develops between the callose and the plasmalemma (fig. 7I), and T-shaped electron-dense material is radially oriented in the proximal part of the plasmalemma surface coat. These elements are the initiation of the columellae and have a length of ca. $0.2 \mu \mathrm{m}$ (fig. 8A-8C). Exine deposition clearly starts at the proximal pole, and the exine elements are thicker and better developed here (figs. 7I, 8E). The aperture sites are equatorial, positioned between the proximal and distal pole and forming an angle of $180^{\circ}$, and they lack deposition of the T-shaped elements. The apertures are parallel to the longest axis of the pollen grain. The cytoplasm of the microspores contains many proplastids (fig. $8 D-8 F$ ). Entire tetrads in the late tetrad stage have a diameter of ca. $30 \mu \mathrm{m}$. Some tetrads are still connected via cytomictic channels that seem to persist into the late tetrad stage (fig. 8G). This is the most productive stage for the tapetal cells, which stain very densely and contain endoplasmic reticulum and electron-dense sporopollenin precursors. Lipid droplets and pro-orbicules are visible in depressions of the tapetal plasmalemma, originating by exocytosis (fig. $8 H$ ).

Free microspore stage (fig. 9). Residual callose is still present between the free microspores in the early free
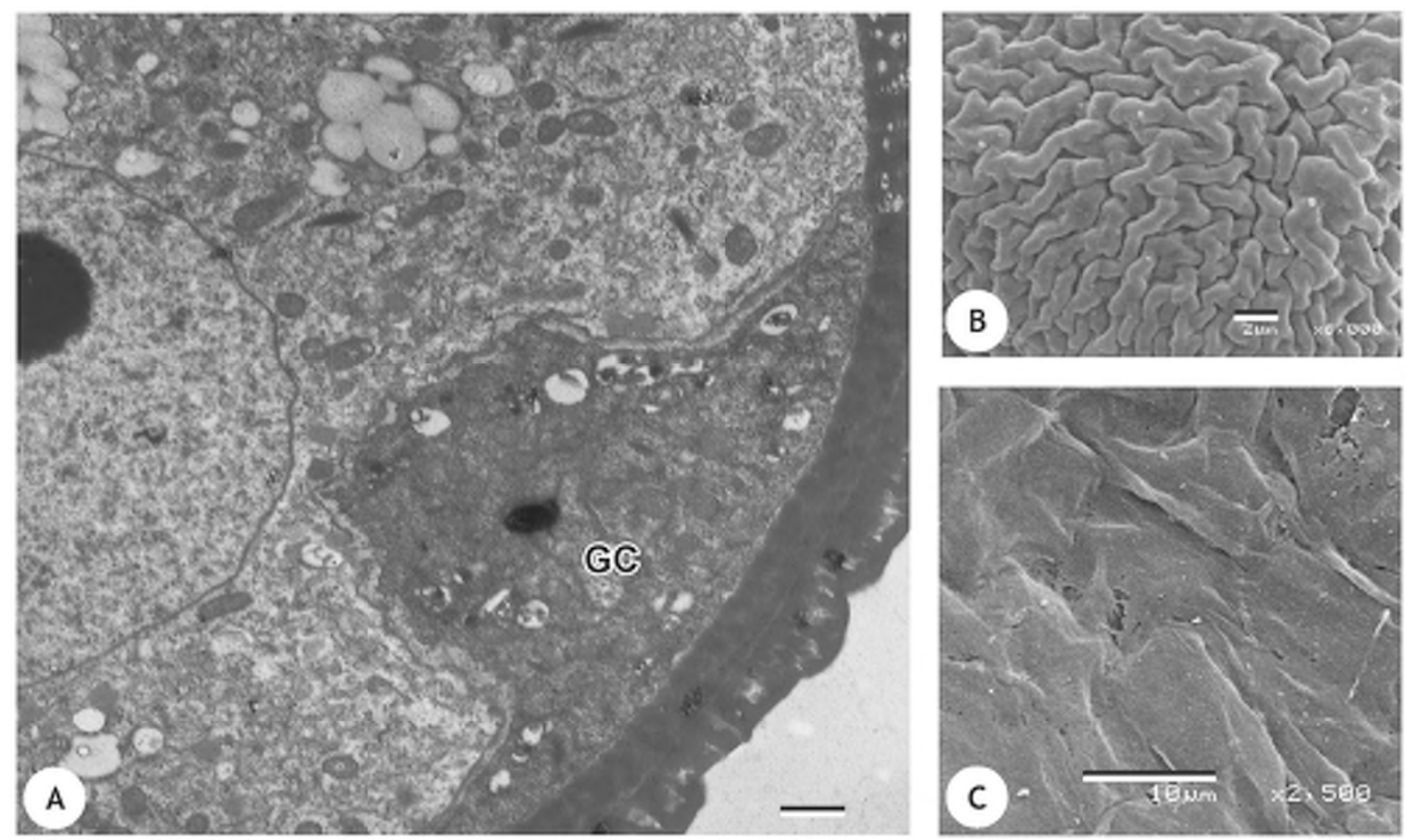

Fig. 6 Tacca chantrieri, mature pollen grain stage. A, Section through a mature pollen grain with the generative cell (GC) situated at the proximal pole, opposite the aperture (TEM). $B$, Detail of the sexine in a mature pollen grain (SEM). C, Tapetal remnants without orbicules (SEM). Bars $=1 \mu \mathrm{m}$ in $A ; 2 \mu \mathrm{m}$ in $B ; 10 \mu \mathrm{m}$ in $C$. 

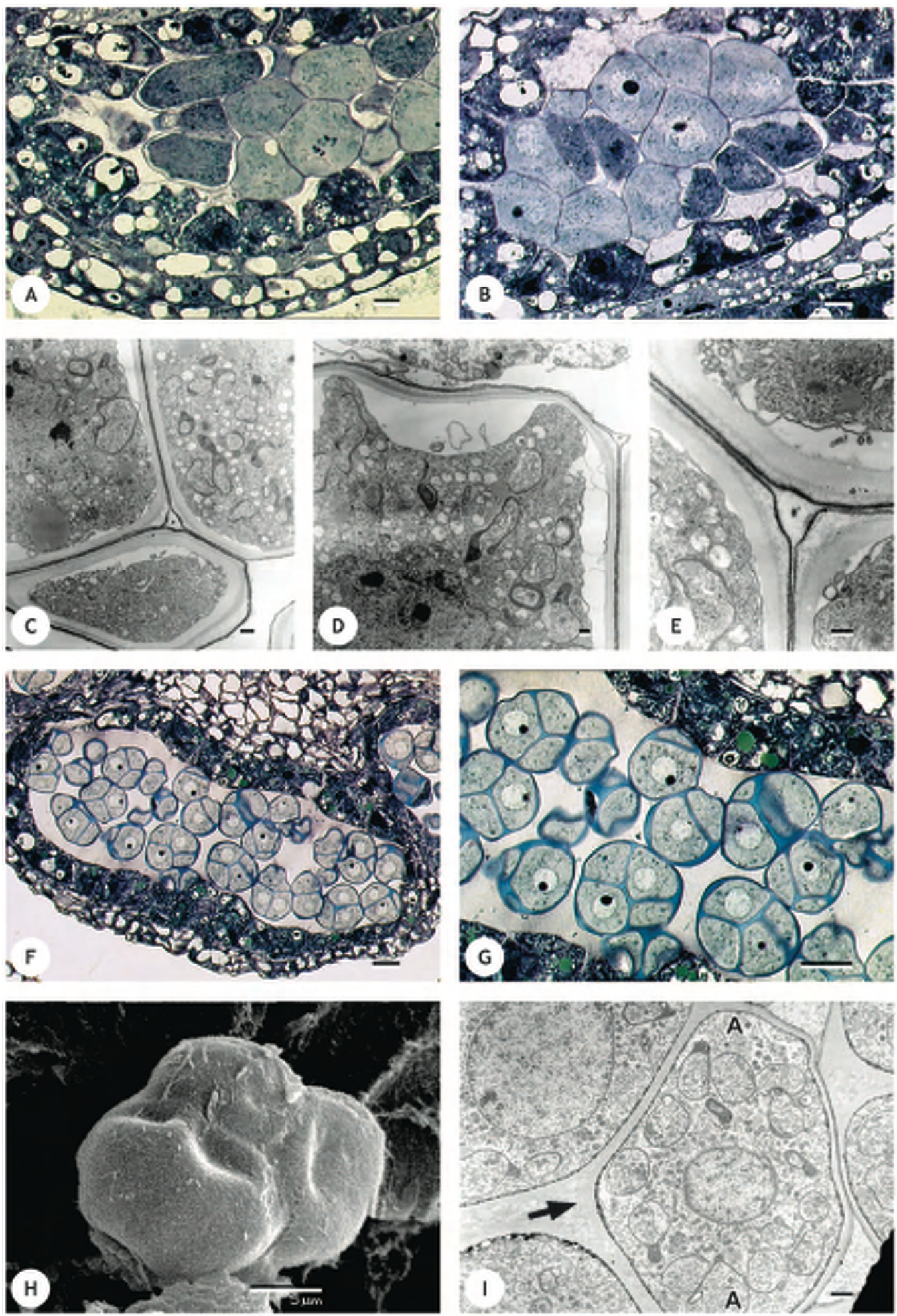

Fig. 7 Dioscorea communis, microsporocyte stage and tetrad stage. A-E, Microsporocyte stage. A, Section through an anther locule with early microsporocytes and densely stained tapetum (LM). B, Section through an anther locule with either mono- or binucleate tapetal cells (LM). $C$, Section through microsporocytes surrounded by thick callose walls (TEM). D, Detail of a microsporocyte with an undulating plasmalemma (TEM). E, Detail of microsporocytes surrounded by thick callose walls. The cytoplasm contains many vesicles (TEM). F-I, Tetrad stage. F, Section through an anther locule filled with tetrahedral tetrads (LM). G, Detail of $F$. The tapetum contains many densely staining substances (LM). $H$, A tetrahedral tetrad surrounded by callose (SEM). I, An early tetrad with a microspore showing one of the two future aperture sites $(A)$ lacking exine synthesis, which is most advanced at the proximal pole (arrow) (TEM). Bars $=10 \mu \mathrm{m}$ in $A, B, F, G ; 1 \mu \mathrm{m}$ in $C-E, I ; 5 \mu \mathrm{m}$ in $H$. 

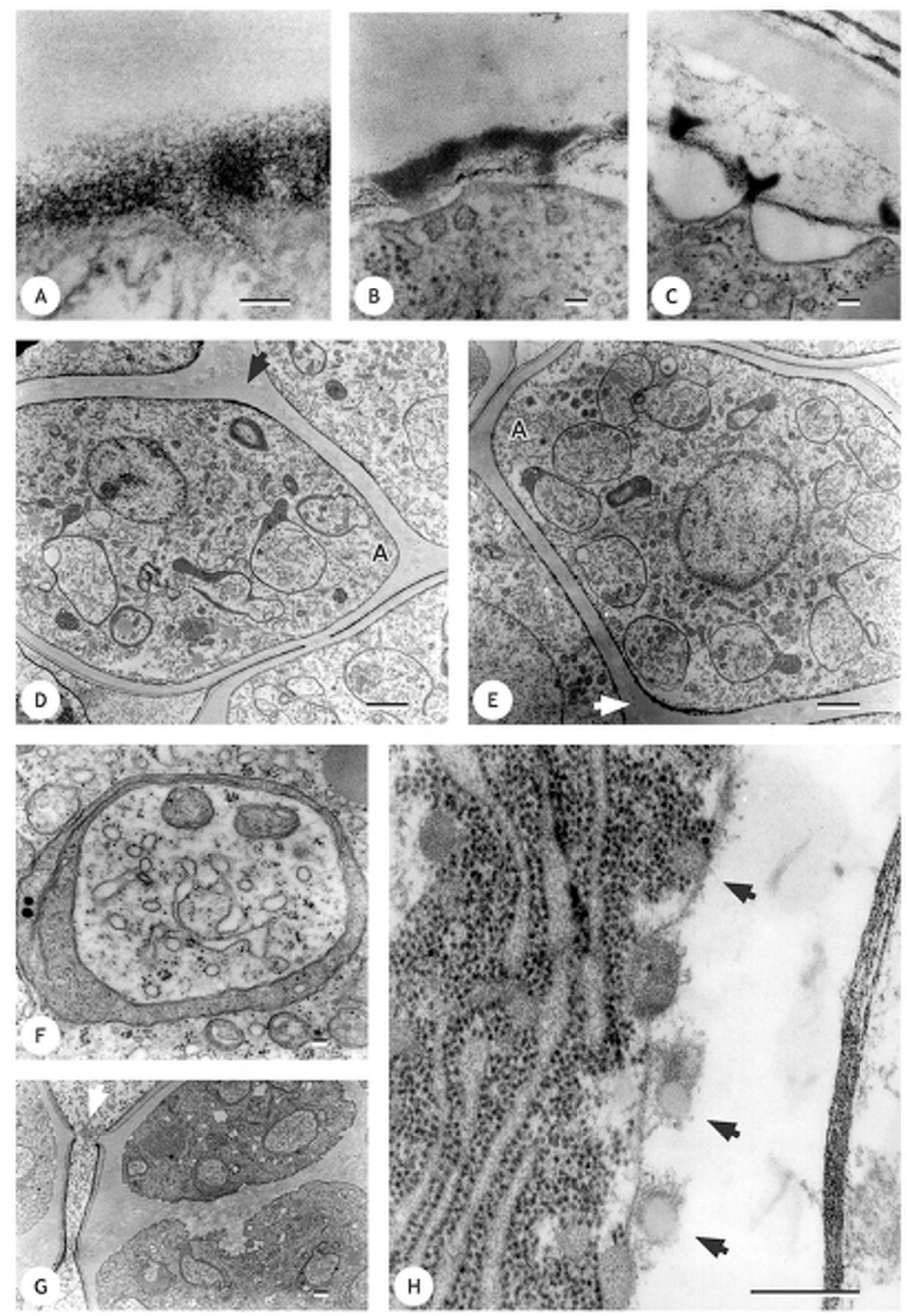

Fig. 8 Dioscorea communis, tetrad stage. A, Section with the primexine matrix developing in the early tetrad stage (TEM). B, Deposition of T-shaped elements in the primexine matrix (TEM). C, Slightly later stage than in $B$. The plasma membrane is highly undulated, and the T-shaped exine elements are clearly visible (TEM). D, A microspore in a tetrad. The primexine deposition clearly starts at the proximal pole (arrow). Cytomictic channels are still present between adjacent tetrads. $(A=$ aperture) $(\mathrm{TEM})$. E, Another microspore with primexine deposition at the proximal pole (arrow) and no exine deposition near the aperture $(A)$. The microspore contains many plastids (TEM). F, Detail of a plastid in the cytoplasm of a microspore (TEM). G, Detail of cytomictic channel (arrow) (TEM). H, Section through the tapetum containing many rough endoplasmic reticulum strands. Pro-orbicules are visible at the tapetal plasmalemma (arrows) (TEM). Bars $=0.1 \mu \mathrm{m}$ in $A-C, F ; 1 \mu \mathrm{m}$ in $D, E, G, H$. 
microspore stage (fig. 9A). Each microspore then develops a large vacuole comprising up to $70 \%$ of the volume of the microspore and with a diameter of ca. $21 \mu \mathrm{m}$ (fig. 9B-9D). The exine is well developed (fig. 9E). The two sulculi are now clearly visible because of their minimal amount of exine deposition (fig. 9F, 9G). Orbicules of ca. 0.3-0.5 $\mu \mathrm{m}$ diameter line the surface of the tapetal cells on the inner and outer tangential walls as well as on the radial surfaces. The orbicules have an electron-lucent core of $0.1-0.2 \mu \mathrm{m}$. At this stage, the tapetum starts to degenerate.

In the late free microspore stage, the microspores still contain many vacuoles as well as starch grains and lipid droplets. The outer, channeled layer of the intine is present only beneath the apertures (fig. 9H). As in Narthecium, intine initiation precedes mitosis.

Pollen grain stage (fig. 10). Mature Dioscorea communis pollen is disulculate, with two elongated apertures situated between the proximal and distal poles (fig. 10A-10C). In outline, the pollen grains have a curved proximal pole and a flattened distal pole (fig. 10B). The exine is ca. $1.1 \mu \mathrm{m}$ thick at anther dehiscence, and the foot layer, tectum, and columellae are well differentiated. The ultrastructure of the tectum results in a perforate sexine as observed using SEM (fig. 10C, 10E). The intine has increased in thickness, and two layers are present. The first is a channeled layer with channels arranged in a characteristic polygonal structure (fig. $10 G$ ), which is very conspicuous in the apertural regions (up to $1 \mu \mathrm{m}$ thick; fig. 10F) and very thin to nonexistent in the nonapertural regions (fig. 10D, 10F). The second layer is a thin endintine (ca. $0.3 \mu \mathrm{m}$ thick) covering the entire pollen grain (fig. 10D). The generative cell is situated at the proximal pole as far away as possible from both apertures (fig. 10B). As in Narthecium and Tacca, the pollen contains many compound starch grains, and starch seems to be the main cytoplasmic storage product. The tapetum has almost entirely degenerated, leaving cytoplasmic remnants together with orbicules on the locule walls (fig. 10H). The orbicules have a diameter of ca. 0.3-0.4 $\mu \mathrm{m}$.

\section{Discussion}

\section{Anther Wall Layers and Number of Tapetal Nuclei}

The structure of the anther wall appears very similar across all species in this study. It consists of an epidermis; an endothecial layer; and mostly one, sometimes two, and (in Narthecium) rarely three middle layers. This anther wall structure is the most common within angiosperms (Pacini 1994), and within lilioids a similar structure has been found in other Dioscoreaceae (e.g., in Stenomeris; Caddick et al. 1998) and Liliaceae (Takahashi 1987). The tapetum is mostly one cell layer thick and uninucleate, although it is sometimes binucleate.

\section{Microsporocytes and Cytomictic Channels}

Cytomictic channels have been found in all three genera examined. These channels are present in many families such as Fabaceae (Xi 1991) and Malvaceae (Sarvella 1958) and are probably a feature of all angiosperm microsporocytes (Whelan et al. 1974). In Orchidaceae, they persist until the mature pollen grain stage (Shukla et al. 1998). At least in Di- oscorea, cytomictic channels persist into the tetrad stage. These channels facilitate cell to cell communication (McLean et al. 1997). Cytomictic channels have also been reported to enable transfer of chromatin between adjacent microsporocytes in Brassicaceae (Malallah and Attia 2003). According to Heslop-Harrison (1971), formation of channels between microsporocytes enables them to share a common cytoplasm and effectively function as a syncytium, enabling synchronization of meiosis.

\section{Microsporogenesis and Tetrad Configuration}

Tetrad configuration is correlated with microsporogenesis type (Rudall et al. 1997; Furness and Rudall 1999; Furness et al. 2002). Narthecium, with successive microsporogenesis, has tetragonal tetrads, while Tacca and Dioscorea have simultaneous microsporogenesis and tetrahedral tetrads, confirming the results of Caddick et al. (1998) and Furness and Rudall (1999). The shift from successive microsporogenesis in Nartheciaceae (and Burmanniaceae; Caddick et al. 1998) to simultaneous microsporogenesis in Dioscoreaceae (including Tacca) did not affect the aperture type directly. Both Narthecium and Tacca have monosulcate pollen with one aperture at the distal pole. This indicates that tetrad configuration is not the sole factor determining aperture number and position, although it may play an important role in aperture development. On the other hand, it might be that the shift from successive to simultaneous cytokinesis has enabled the shift to occur from monosulcate apertures in Tacca and Dioscorea section Stenophora (sister to other Dioscorea species) to the disulculate type found in the rest of Dioscorea (fig. 1; Schols et al., forthcoming).

\section{Aperture Formation}

Apertural regions are characterized by their lack of exine deposition in the early to midtetrad stage. Ressayre (2001) summarized several mechanisms inducing the formation of apertures, such as the prevention of primexine deposition by shields of endoplasmatic reticulum, callose knobs, or interstitial bodies or through another mechanism in which exine outgrowth breaks up during microspore expansion to expose the intine. None of these mechanisms were observed in the species we have studied. The presence of shields of endoplasmic reticulum or callose knobs should be detectable with TEM. The only unusual cellular activity beneath the future aperture sites in early tetrads is the presence of a high number of Golgi vesicles. The aperture site for both Narthecium and Tacca is positioned at the distal pole, and one distal sulcus is the most common condition within monocots. In Dioscorea, two elongated apertures appear in the midtetrad stage, positioned between the proximal and distal poles. Apertures in Dioscorea are equatorial and parallel to the longest axis of the grain and are referred to as sulculi (Punt et al. 1998). As discussed above, simultaneous microsporogenesis might be necessary to develop this kind of aperture configuration, although disulculate pollen has also been reported in taxa with successive microsporogenesis, e.g., Pontederiaceae species (Ressayre 2001). 

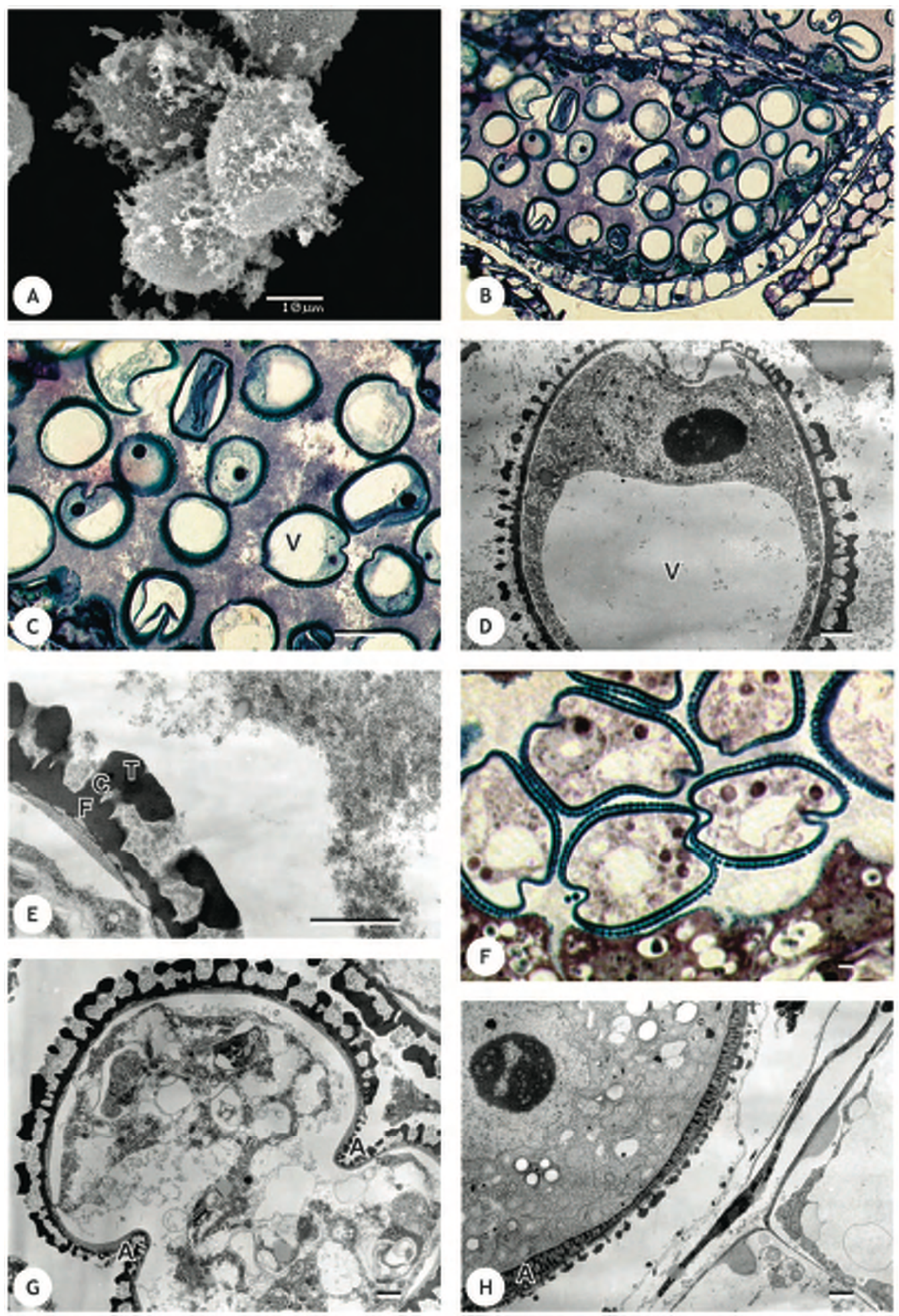

Fig. 9 Dioscorea communis, free microspore stage. A, Individual microspores released from a tetrahedral tetrad by the dissolving callose (SEM). B, An anther locule with free microspores at the vacuolate stage. The vacuole takes up a very large proportion of each microspore, and the cytoplasm is pressed against the microspore wall (LM). C, Detail of $B(V=$ vacuole) (LM). $D$, Section through a vacuolate microspore $(V=$ vacuole) (TEM). E, Exine ultrastructure at the vacuolate stage. Tectum $(T)$, columellae $(C)$, and foot layer $(F)$ are present (TEM). F, Section through microspores at the late free microspore stage. The disulculate apertures can be seen (LM). $G$, Section through a microspore at the late free microspore stage. The two apertures $(A)$ can be recognized by their reduced amount of exine deposition (TEM). $H$, Detail of a section through a late free microspore showing the thin, channeled intine present in this stage $(A=$ aperture) (TEM). Bars $=10 \mu \mathrm{m}$ in $A-C$; $1 \mu \mathrm{m}$ in $D-H$. 

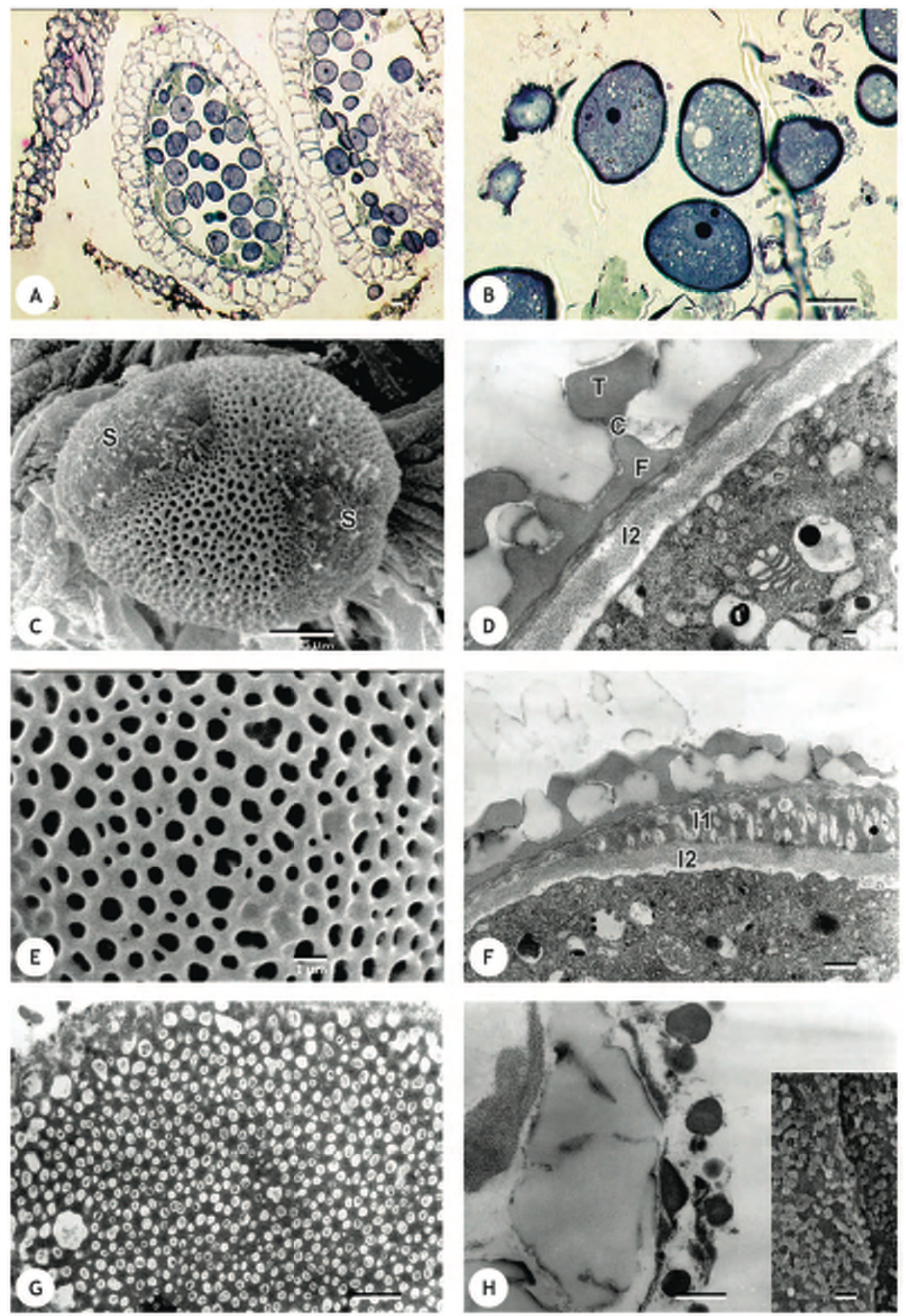

Fig. 10 Dioscorea communis, mature pollen grain stage. A, Section through the anther locules just before anthesis (LM). B, Pollen grains at anthesis with both the vegetative and generative cells visible in some grains. The generative cell is always located at the proximal pole, as far away from the apertures as possible. The intine stains densely beneath the sulculi (LM). C, Overview of a mature pollen grain showing the sulculi $(S)$ (SEM). D, Exine ultrastructure showing tectum $(T)$, columellae $(C)$, and foot layer $(F)$. A thin endintine $(I 2)$ is present (TEM). E, The perforate sexine surface (SEM). F, Wall ultrastructure near a sulculus. The channeled intine (I1) is only present beneath the apertures while the endintine (I2) surrounds the entire pollen grain. $G$, A tangential section through the intine. The electron-lucent channels are arranged in polygonal structures (TEM). H, Mature orbicules covering the tapetal remnants. (main image, TEM; inset, SEM). Bars $=10 \mu \mathrm{m}$ in $A, B ; 5 \mu \mathrm{m}$ in $C ; 0.1 \mu \mathrm{m}$ in $D ; 1 \mu \mathrm{m}$ in $E, G ; 0.5 \mu \mathrm{m}$ in $F$. 


\section{Exine Formation}

The first T-shaped exine elements, consisting of procolumellae and a pro-tectum, are deposited in the primexine matrix around the midtetrad stage. In the late tetrad stage, these elements become thicker, and a foot layer becomes visible. In Dioscoreales, the exine ultrastructure is completely determined during the tetrad stage. In the free microspore stage, the exine thickness increases significantly, becoming up to three times thicker. All species in this survey have a perforate or rugulate sexine lacking the supratectal elements found in striate Dioscorea species (Schols et al. 2001). No indication of endexine deposition was observed in any of the taxa examined in this study, although Schols et al. (2001) described white lines beneath the foot layer in mature pollen of Dioscorea sylvatica Eckl.

\section{Intine Ontogeny and Ultrastructure}

All three genera possess a well-developed intine consisting of two layers: a thick, channeled outer layer and a thin inner layer. The outer layer (or exintine) has electron-lucent channels arranged in a polygonal structure, as seen in tangential sections (figs. 4F, 10G). This layer forms beneath the apertures in all three genera, but in Tacca it also occurs in the nonapertural regions. A well-developed intine in general and these channels in particular seem to characterize many monocot genera; for example, they have been reported in Liliales (Nakamura 1979), Asparagales (Suárez-Cervera et al. 2000), Zingiberales (Kress and Stone 1982), and Poaceae (El-Ghazaly and Jensen 1986, 1987).

Suárez-Cervera et al. (2000) carried out a detailed ontogenetic study of the intine in Aristea major (Iridaceae) and concluded that three distinct layers were present: a pectic exintine, a pectic proteinic channeled middle layer, and a fibrillar cellulosic endintine. The two intine layers observed in Dioscoreales in our study correspond to the middle intine layer and the endintine of Suárez-Cervera et al. (2000), and the pectic exintine layer on top of the channeled intine is absent. The same two layers were also found in Canna (Rowley and Skvarla 1986) and Zingiber (Theilade and Theilade 1996), which also lack exintine. Possible roles of the thick, channeled intine include prevention of gametophyte desiccation during pollination, release of enzymes related to pollen tube growth, and control of the enlargement of the apertural region (Suárez-Cervera et al. 2000). As in Aristea, the intine in Dioscoreales develops during the free microspore stage, after the vacuolate microspore stage. Intine generally develops after mitosis in angiosperms (Shukla et al. 1998). In Dioscoreales, however, intine is clearly present during the free microspore stage, before microspore mitosis. This has also been demonstrated in Lilium and Silene (Heslop-Harrison 1968).

\section{Position of the Generative Cell}

The generative cell is located at the opposite side of the pollen grain to the aperture in the monosulcate species examined (Narthecium ossifragum and Tacca artocarpifolia) and as far away from both apertures as possible in the disulculate Dioscorea communis pollen. In both cases, the generative cell is located at the proximal pole. A similar position for the generative cell is described in Haemanthus (Amaryllidaceae: Shukla et al. 1998).

\section{Orbicule Ontogeny and Ultrastructure}

Orbicules are usually correlated with secretory tapeta (Huysmans et al. 1998, 2000). They occur in Narthecium and Dioscorea but not in Tacca, although it has a secretory tapetum as in other Dioscoreales (Furness and Rudall 1998). This confirms previous observations by Schols et al. (forthcoming). Within Dioscoreales, orbicules occur in Dioscorea, Trichopus (L. R. Caddick, personal communication), and Nartheciaceae (V. Merckx, personal communication), while they are absent in Tacca and in Burmanniaceae (P. Schols, unpublished data). No orbicule data is available for Stenomeris. The absence of orbicules in taxa with secretory tapeta is not uncommon within the angiosperms, since it occurs in Brassicaceae, Cactaceae, Cucurbitaceae, Fabaceae, Geraniaceae, Lamiaceae, and Orchidaceae (Huysmans et al. 1998). Why orbicules are lacking in some taxa with secretory tapeta is still unclear.

Pro-orbicules appear on the outside of the tapetal plasmalemma in Narthecium and Dioscorea while primexine polymerization is taking place in the microspores. Soon afterward, they acquire a thin sporopollenin coat that increases in thickness continuously until pollen maturity. In both Narthecium and Dioscorea, the orbicules have an electron-lucent core that is the remains of the pro-orbicule, and this does not appear to increase in size during orbicule development. Around this core is the main electron-dense orbicule layer, referred to as the orbicule wall (Clément and Audran 1993), and outside this is a very electron-dense peripheral layer that can be seen only at high magnifications (fig. $4 \mathrm{H}$, arrow). This orbicule ultrastructure in Dioscoreales is very similar to that found in Lilium (Liliales; Clément and Audran 1993). Orbicules are significantly larger in Narthecium than in Dioscorea, ca. $1.3 \mu \mathrm{m}$ compared with $0.4 \mu \mathrm{m}$.

Table 1

Summary of Ontogenetic Characters

\begin{tabular}{llll}
\hline & Dioscorea & \multicolumn{1}{c}{ Tacca } & Narthecium \\
\hline No. of middle layers & $1-2$ & $1-2$ & $1-2(3)$ \\
Microsporogenesis & Simultaneous & Simultaneous & Successive \\
Tetrad configuration & Tetrahedral & Tetrahedral & Tetragonal \\
Aperture position & Equatorial & Distal & Distal \\
Aperture type & Disulculate & Monosulcate & Monosulcate \\
Channeled intine beneath apertures & Present & Present & Present \\
Channeled intine in nonapertural regions & Absent & Present & Absent \\
Orbicules & Present & Absent & Present \\
\hline
\end{tabular}




\section{Conclusions}

The general pollen ontogenetic pattern described for all three genera of Dioscoreales is relatively similar (table 1 ). This supports the close relationship between the three genera. Nartheciaceae, sister to other Dioscoreales, is characterized by successive microsporogenesis and tetragonal tetrads, while Dioscoreaceae are simultaneous and have tetrahedral tetrads. In Narthecium and Tacca, one distal sulcus develops during the tetrad stage, while in Dioscorea there are two equatorial sulculi. Exine deposition starts in the midtetrad stage in all three genera with the formation of T-shaped elements. All Dioscoreales examined are characterized by a thick intine that consists of two layers. The channeled outer layer is present only beneath the aperture except in Tacca, where it occurs beneath the entire exine. Intine synthesis clearly begins before mitosis in the free microspore stage. Orbicules are present in Dioscorea and Narthecium but lacking in Tacca. They are formed around pro-orbicules that originate from the tapetum at the tetrad stage. Further work is required to determine why pro-orbicules are not produced in Tacca and to understand the mechanisms influencing the shift in microsporogenesis type and aperture number within Dioscoreales.

\section{Acknowledgments}

Our thanks to Surrey County Council and English Nature for permission to collect material of Narthecium ossifragum and to Dr. Eric Schoeters, Marcel Verhaeghen, and Anja Vandeperre for technical assistance. Peter Schols is a postdoctoral fellow of the Katholieke Universiteit Leuven (PDM/04/ 136). Vincent Merckx holds a research grant from the Institute for the Promotion of Innovation through Science and Technology in Flanders (Instituut voor de aanmoediging van innovatie door wetenschap en technologie in Vlaanderen, 31536). This research is supported by a grant from the Fund for Scientific Research-Flanders, Belgium (Fonds voor Wetenschappelijk Onderzoek-Vlaanderen, G.0250.05).

\section{Literature Cited}

Caddick LR, CA Furness, KL Stobart, PJ Rudall 1998 Microsporogenesis and pollen morphology in Dioscoreales and allied taxa. Grana 37:321-336.

Caddick LR, PJ Rudall, P Wilkin, MW Chase 2000 Yams and their allies: systematics of Dioscoreales. Pages 475-487 in KL Wilson, DA Morrison, eds. Systematics and evolution of monocots. Proceedings of the 2nd International Monocot Conference. CSIRO, Melbourne.

Caddick LR, PJ Rudall, P Wilkin, TAJ Hedderson, MW Chase $2002 b$ Phylogenetics of Dioscoreales based on combined analyses of morphological and molecular data. Bot J Linn Soc 138: 123-144.

Caddick LR, P Wilkin, PJ Rudall, MW Chase, TAJ Hedderson 2002a A formal revised classification of Dioscoreales. Taxon 51: 103-114.

Chakrapani P, B Raj 1971 Pollen morphological studies in the Burmanniaceae. Grana 11:164-179.

Clément C, JC Audran 1993 Electron microscope evidence for a membrane around the core of the Ubisch body in Lilium (Liliaceae). Grana 32:311-314.

El-Ghazaly G, WA Jensen 1986 Studies of the development of wheat (Triticum aestivum) pollen. Grana 25:1-29.

1987 Development of wheat (Triticum aestivum) pollen. II. Histochemical differentiation of wall and Ubisch bodies during development. Am J Bot 74:1396-1418.

Furness CA, PJ Rudall 1998 The tapetum and systematics in monocotyledons. Bot Rev 64:201-239.

1999 Microsporogenesis in monocotyledons. Ann Bot 84: 475-499.

Furness CA, PJ Rudall, FB Sampson 2002 Evolution of microsporogenesis in angiosperms. Int J Plant Sci 163:235-260.

Heslop-Harrison J 1968 Pollen wall development. Science 161: 230-237.

1971 The cytoplasm and its organelles during meiosis. Pages 16-31 in J Heslop-Harrison, ed. Pollen: development and physiology. Butterworths, London.

Huysmans S, G El-Ghazaly, E Smets 1998 Orbicules in angiosperms: morphology, function, distribution, and relation with tapetum types. Bot Rev 64:240-272.

2000 Orbicules: still a well-hidden secret of the anther. Pages 201-212 in B Nordenstam, G El-Ghazaly, M Kassas, TCX Laurent, eds. Plant systematics for the 21st century. Wenner-Gren International Series. Vol 77. Portland, London.

Kress WJ, DE Stone 1982 Nature of the sporoderm in monocotyledons, with special reference to the pollen grains of Canna and Heliconia. Grana 21:129-148.

Kreunen SS, JM Osborn 1999 Pollen and anther development in Nelumbo (Nelumbonaceae). Am J Bot 86:1662-1676.

Malallah GA, TA Attia 2003 Cytomixis and its possible evolutionary role in a Kuwaiti population of Diplotaxis harra (Brassicaceae). Bot J Linn Soc 143:169-175.

McLean BG, FD Hempel, PC Zambryski 1997 Plant intercellular communication via plasmodesmata. Plant Cell 9:1043-1054.

Nakamura S 1979 Development of the pollen grain wall in Lilium longiflorum. J Electron Microsc 28:275-284.

Pacini E 1994 Tapetum types in the Compositae: forms and function. Pages 21-28 in DJN Hind, HJ Beentje, eds. Compositae: systematics. Proceedings of the International Compositae Conference. Vol 1. Royal Botanic Gardens, Kew.

Punt W, S Blackmore, S Nilsson, A Le Thomas 1998 Glossary of pollen and spore terminology. http://www.biol.ruu.nl/ palaeo/ glossary/.

Ressayre A 2001 Equatorial aperture pattern in the monocots: same definition rules as in eudicots? the example of two species of Pontederiaceae. Int J Plant Sci 62:1219-1224.

Rowley JR, JJ Skvarla 1986 Development of the pollen wall in Canna. Nord J Bot 6:39-65.

Rudall PJ, CA Furness, MW Chase, MF Fay 1997 Microsporogenesis and pollen sulcus type in Asparagales (Lilianae). Can J Bot 75: 408-430.

Sarvella P 1958 Cytomixis and loss of chromosomes in meiotic and somatic cells of Gossypium. Cytologia 23:14-24.

Schols P, S Dessein, C D'hondt, S Huysmans, E Smets 2002 Carnoy: a new digital measurement tool for palynology. Grana 41: 124-126.

Schols P, CA Furness, P Wilkin, S Huysmans, E Smets 2001 Morphology of pollen and orbicules in some Dioscorea (Dioscoreaceae) species and its systematic implications. Bot J Linn Soc 136: 295-311.

Schols P, CA Furness, P Wilkin, E Smets, V Cielen, S Huysmans 2003 Pollen morphology of Dioscorea (Dioscoreaceae) and its relation to systematics. Bot J Linn Soc 143:375-390. 
Schols P, P Wilkin, CA Furness, S Huysmans, E Smets 2005 Pollen evolution in yams (Dioscorea: Dioscoreaceae). Syst Bot (forthcoming).

Shukla AK, MR Vijayaraghavan, B Chaudry 1998 Biology of pollen. APH, New Delhi.

Suárez-Cervera M, A Le Thomas, P Goldblatt, J Márquez, JA SeoaneCamba. 2000. The channeled intine of Aristea major: ultrastructural modifications during development, activation and germination. Pages 57-71 in MM Harley, CM Morton, S Blackmore, eds. Pollen and spores: morphology and biology. Royal Botanic Gardens, Kew.
Takahashi M 1987 Development of omniaperturate pollen in Trillium kamtschaticum (Liliaceae). Am J Bot 74:1842-1852.

Theilade I, J Theilade 1996 Ontogeny of pollen grains in Zingiber spectabile (Zingiberaceae). Grana 35:162-170.

Whelan EDP, GH Haggis, EJ Ford 1974 Scanning electron microscopy of the callose wall and intermeiocyte connections in angiosperms. Can J Bot 52:1215-1218.

X-Y Xi 1991 Development and structure of the pollen and embryo sac in peanut (Arachis hypogaea L.). Bot Gaz 152:164-172. 